\title{
ESSENSIAL OIL DAN PEMANFAATAN ERYNGIUM FOETIDUM L. SEBAGAI OBAT TRADISIONAL
}

\author{
Marina Silalahi \\ Prodi Pendidikan Biologi FKIP, Universitas Kristen Indonesia, Jakarta. \\ *marina_biouki@yahoo.com; marina.silalahi@uki.ac.id
}

\begin{tabular}{|c|c|}
\hline & Abstract \\
\hline $\begin{array}{l}\text { Keywords: } \\
\text { Eryngium } \\
\text { foetidum, } \\
\text { antimicbial, } \\
\text { essential oil }\end{array}$ & $\begin{array}{l}\text { Eryngium foetidum }(E F) \text { is one of the Apiaceae family that is used as } \\
\text { medicine, vegetables and cooking spices. Plants that are used as medicine } \\
\text { are directly or indirectly related to the content of secondary metabolites. } \\
\text { The writing of this article is based on a literature review obtained from } \\
\text { various online sources (mainly from google schoolar and scopus) and } \\
\text { offline (books and other research results) using EF keywords, then } \\
\text { synthesized to explain the benefits and bioactivity of EF. In ethnobotany } \\
\text { fever, hypertension, headache, abdominal pain, asthma, arthritis, } \\
\text { diarrhea, and malaria. The essential oil contained in EF is dominated by } \\
\text { (E) -2-dodecenal, dodecanoic acid, trans-2-dodecanoic acid }(9.7 \%),(E) \text { - } \\
\text { 2-tridecenal, duraldehyde, and tetradecanal. EF's bioactivity has been } \\
\text { proven to be anti-microbial, antioxidant and anti-natural. The ability of } \\
\text { EF essential oils as an anti-microbial is very potential to be developed as } \\
\text { a natural food preservative. }\end{array}$ \\
\hline
\end{tabular}

\section{PENDAHULUAN}

Tumbuhan sebagai bahan obat dan bahan pangan memainkan peran yang sangat penting dalam perkembangan peradapan manusia. Pencaharian dan penelitian tumbuhan yang berdampak langsung atau tidak langsung terhadap kesehatan terus dilakukan sebagai agen terapi alternatif baru untuk perawatan kesehatan. Dilaporkan lebih dari 7.000 spesies tumbuhan berhasiat obat. Khasiat tumbuhan dalam penyembuhan penyakait berhubungan dengan senyawa bioaktif alami mereka seperti fenol, flavonoid, tanin (Erdem et al 2015).

Eryngium foetidum (EF) merupakan salah satu species dalam famili Apiaceae yang dimanfaatkan sebagai sayuran, bumbu masak, dan obat. Dawilai et al. (2013) menyatakan bahwa EF telah digunakan sebagai rempah-rempah kuliner di berbagai daerah tropis (Dawilai et al 2013), hiasan, asinan, penyedap, dan bumbu makanan (Singh et al 2014). Di berbagai negara EF dibudidayakan sebagai tanaman hias, sayuran, atau tanaman obat (Wang et al 2012), namun di Indonesia pada umumnya tumbuh liar bahkan dianggap sebagai gulma. Walaupun, EF merupakan tanaman asli Karibia (Garcia et al 1999), namun di Indonesia sangat mudah ditemukan di berbagai lanskap seperti pekarangan, pematang sawah, kebun, dan tepi jalan. Tanaman mudah dikenali dari aroma tajam dan khas ketika organnya disentuh serta permukaan tubuh yang dilengkapi dengan duri (Gambar 1) (van den Berg 1999), sehingga dijuluki juga sebagai ketumbar berduri (Singh et al 2014). Aroma yang dihasilkan EF sangat tajam (Singh et al 2014), diduga berhubungan dengan kandungan volatil oil atau essential oil.

Banyaknya manfaat EF dalam industri makanan mengakibatkan EF merupakan tanaman yang memiliki nilai ekonomi (Singh et al 2014). Dalam pengobatan tradisional EF digunakan untuk mengatasi 
sejumlah penyakit seperti demam, hipertensi, sakit kepala, sakit telinga, sakit perut, asma, radang sendi, diare, malaria, dan epilepsi (Singh et al 2014; Wang et al 2012). Penggunaan tumbuhan pangan sebagai obat memiliki kelebihan kerena pengelolaannya relatif lebih mudah karena proses pengolaannya bersamaan dengan bahan pangan lainnya. Mabeku et al (2013) menyatakan bahwa penggunaan EF sebagai bahan pangan juga berdampak terhadap kesehatan saluran pencernaan karena dapat menghambat pertumbuhan bakteri patogen Helicobacter pylori (Mabeku et al 2013).

Walaupun kajian tentang EF sudah banyak namun pembahasan yang menghubungkan metabolit sekunder dan bioaktivitasnya masih terbatas terutama yang berbahasa Indonesia. Anggapan bahwa pemanfaatan tumbuhan sebagai obat relatif lebih aman dibandingkan dengan senyawa sintetis tidaklah sepenuhnya benar. Ketetapatan dosis, cara pengolahan maupun seumber bahan baku sangat perlu sehingga meminimalisasi efek smapingnya. Pemanfaatan tumbuhan sebagai obat berhubungan dengan kandungan senyawa bioaktif atau metabolit sekundernya. Kajian ini akan memberikan informasi mengenai pemnfaatan EF dan bioaktivitasnya sehingga dapat dijadikan sebagai salah satu informasi dalam pengembangan $\mathrm{EF}$ sebgai obat tradisional maupun herbal terstandart.

\section{METODE}

Penulisan artikel ini didasarkan pada kajian literare terhadap berbagai buku, hasil penelitian yang terbit secara online maupun offline. Literature diperoleh dari Scopus, Google scholar, dan jurnal lainnya dengan menggunakan kata kunci Erygium foetida, Bioactivities EF dan Metabolites secondary EF. Hasil yang diperoleh disintesakan sehingga diperoleh informasi yang konfrehensif mengenai pemanfaatan, bioaktivitas dan metabolit sekunder dari EF.

\section{HASIL DAN PEMBAHASAN \\ Botani Eryngium foetidum}

Eryngium L. merupakan salah satu genus yang sangat komplek dalam famili Apiaceae. Diperkirakan Eryngium memiliki sekitar 250 species yang tersebar hampir diseluruh dunia dengan pusat penyebaran Amerika Selatan. Salah satu genus yang banyak dimanfaatkan adalah Erygium. Genus Eryngium diperkirakan memiliki lebih dari 250 spesies (Erdem et a 2015) dan digunakan sebagai bahan pangan dan obat. Eryngium foetida Eryngium antihystericum Rottler merupakan salah satu species yang telah lama dibudidayan dan dimanfaatkan sebagai penghasil essensial oil (van der Berg 1999) merupakan sinonin dengan.

Asal usul EF tidak diketahui secara pasti tetapi di duga berasal dari Amerika Tengah dan Amerika Selatan (van den Bergh 1999) dan merupakan tanaman endemik Karibia (Garcia et al 1999). Masyarakat lokal di Indonesia mengenal EF dengan nama walangan (Jakarta), ketumbar Jawa (Sumatera), dan tumbar mungsi (Jawa). Daun EF memiliki aroma mirip dengan ketumbar dan karena asalnya dari Amerika Tengah dikenal juga dengan nama Ketumbar Mexico. Dalam kuliner daun digunakann untuk berbagai masakan seperti sop, kari dan daun muda digunakan sebagai lalapan atau sayur. EF telah lama dibudidayakan di Amerika Selatan, di Vietnama, Thailand, Philipina, Cambodia dan Jepang (van den Bergh 1999).

Di Asia Tenggara tanaman ini merupakan tanaman intoduksi diduga menyebar melalui etnis China. Di Pulau Jawa, EF dikenal sejak 1896 sedangkan di sumatera telah dikenal sejak 1915 (6van den Bergh 1999). Eryngial merupakan salah satu senyawa essensial oil utama yang terpenting dalam genus Eryngium yang memiliki aktivitas sebagai anti bakteri (Erdem et al 2015).

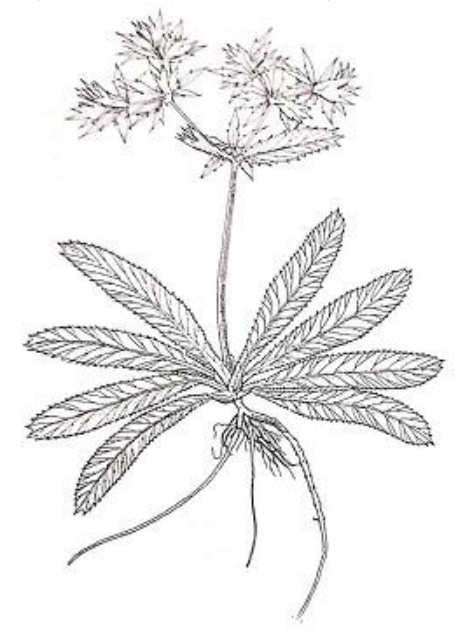

Gambar 1. Habitus Erygium foetidum 
Erigyum foetidum merupakan herba menahun yang tumbuh tegak dan hapat tumbuh dengan tinggi dapat mencapai $80 \mathrm{~cm}$ dan sering memiliki percabangan. Bentuk akar menyerupai tombak atau dikenal juga sebagai taproot. Batang membentuk roset dan akan memanjang ketika mau berbunga dengan percabangan yang dikasial (Gambar 1). Daun merupakan tunggal yang duduk sub sesil dan membentuk roset dan menghasilkan bau ketika diremas. Bentuk helaian lanceolata-obate hingga spatulate-oblong dengan ukuran 5-32 $\mathrm{cm} \times 1-4 \mathrm{~cm}$. Bagian basal daun membentuk seperti selubung. Bagian pinggir daun berduri serrate. Pembungaan muncul dari bagian terminal atau ujung berbentuk seperti kepala paku dan bercabang membentuk seperti corymb, dan memunculkan 2 braktea. Brakteanya kaku dengan panjang 1-6 cm dan sering menyerupai daun normal.Bunga subsesil dengan kalik berbetuk tubuler dengan panjang sekitar $1 \mathrm{~mm}$ dengan 5 yang kecil, tegak dan gigi segitiga. Petal berjumlah 5 dan berbentuk elliptical-oblong denga ukuran 0,5-0,75 $\mathrm{mm} \times 0,25 \mathrm{~mm}$ bewarna putih kehijauan, dan bagian ujungnya melengkung. Stamen berjumlah 5 dan pistil memiliki 2 tangkai filiform. Buah berbentuk schizocarp ovoid-obovoid dengan ukuran 0,5 mm x 0,75 mm (van den Bergh 1999).

\section{Metabolit Sekunder}

Metabolit sekunder merupakan senyawa yang dihasilkan oleh tumbuhan dari proses metabolisme sekunder. Berdasarkan proses sintesisnya metebolit sekunder dibedakan menjadi alkaloid, phenolik dan terpenoid (Taiz and Zeinger 2006). Terpenoid sangat beragam dalam struktur maupun fungsinya, namun dapat dikelompokkan menjadi monoterpenoid, seskuiterpenoid, diterpenoid dan triterpenoid. Monoterpenoid dan seskuiterpenoid merupakan senyawa yang mudah menguap dan merupakan salah satu kelompok essensial oil, oleh karena itu menghasilkan aroma yang khas (Oyen and Dung 1999).

Eryngium foetidum yang dikenal juga sebagai sebagai ketumbar berduri (1Bhavana et al 2013). EF dikenal sebagai tanaman aromatik dan dalam Plant Resources of South
East Asia 13 kedalam tumbuhan spices (de Guzman dan Siemonsma 1999) yaitu tumbuhan yang digunakan sebagi rempah. EF merupakan tanaman aromatik yang mengandung $0,1-0,95 \%$ minyak esensial. Tanaman ini juga digunakan sebagai pengganti ketumbar dan mengandung zat besi, karoten, riboflavin, kalsium, vitamin dan saponin yang khas (Bhavana et al 2013). Tanaman ini banyak digunakan sebagai bumbu penyedap makanan dan bumbu untuk berbagai hidangan. Kandungan metabolit sekunder EF bervariasi dipengaruhi oleh ecotipenya (Bhavana et al 2013). E. foetidum dikumpulkan dari Andaman, Darjeeling dan Karnataka memiliki kandungan total fenol, flavonoid, tannin dan kandungan vitamin $\mathrm{C}$ yang berbeda-beda. Kandungan fenolik EF tinggi di Darjeeling sampel sedangkan, sampel Andaman menunjukkan jumlah flavonoid dan tanin yang tinggi. Sampel dari Karnataka kaya kandungan vitamin C (Bhavana et al 2013).

Komposisi essensial oli pada EF diperkirakan 60 (Singh et al 2014) - 81 jenis (Ngang et al 2014) yang dipengaruhi terutama oleh variabilitas genetik dan geografis lokasi (Singh et al 2014). Berbagai metabolit sekunder ditemukan pada EF seperti kolesterol, brassicasterol, campesterol, stigmasterol (sebagai komponen utama sebanyak 95\%) clerosterol, $\beta$ sitosterol, D5-avenasterol, D524stigmastadienol dan D7-avenasterol (Garcia et al 1999). Essensial oil utama yang terdapat pada EF adalah eryngial (E-2-dodecenal) (3) Singh et al 2014), namum kandungan tersebut sangat bervariasi yang dipengaruhi oleh berbagai faktor. Sing et al (2014) menyatakan bahwa EF memiliki banyak variasi yang signifikan dalam morfologi tanaman dan kandungan essensial oil.

Essensial oil atau minyak esensial dihasilkan oleh berbagai tumbuhan termasuk EF dan sering digunakan sebagai penciri spesies tertentu. Kandungan dan jenis essensial oil yang terdapat pada EF sangat bervariasi dipengaruhi oleh asal, usul, metode destilasi, dan metode analisis. Eryngium foetidum dari Bangladesh yang dianalisis dengan menggunakan GC-MS ditemukan sebanyak enam puluh tiga 
senyawa essensial oil dan senyawa dominan yang ditemukan adalah (E) -2-dodecenal $(37,4 \%)$, asam dodecanoic $(10,7 \%)$, asam trans-2-dodecanoic $(9,7 \%)$, (E) -2-tridecenal, $(6,7 \%)$, duraldehyde $(5,1 \%)$ dan tetradecanal $(4,4 \%)$ (Chowdhury et al 2007).

Essensial oil EF dari S.Tomee yang diperoleh dengan cara hidrodestilasi dan dianalisis dengan menggunakan GC, GC/MS dan 13C-NMR ditemukan sejumlah kecil monoterpen hidrokarbon dan seskuiterpenoid dan sejumlah besar senyawa aromatik dan aldehid linier dengan komposisi 2,3,6 trimethylbenzaladehid $(5,5-23,7 \%)$, (E)-2dodecanal (15,9-37,5\%), (E)-2 tetradecenal (18,7-25,3\%) sangat dominan (Salguero dan Cunha, 2003). Hasil fraksinasi kromatografi terhadap ekstrak EF diperoleh berbagai senyawa seperti $\alpha$-kolesterol, brassicasterol, campesterol, stigmasterol (sebagai komponen utama sebanyak 95\%) clerosterol, $\beta$ sitosterol, D5-avenasterol, D524stigmastadienol dan D7-avenasterol (Garcia et al 1999). Hasil hidrodestilasi yang dikumpulkan dalam Clevenger trap dan dianalis dengan GC dan GC/MS. Komponen utama adalah 2,4,5 trimetil benzal aldehid $(27,7 \%)$, (E)-2 dodecanal $(27,5 \%)$, carotol $(8,8 \%)$, 3-dodecanal $(5,2 \%)$ dan gammaterpinene $(3,5 \%)$ (Rubio et al 2004). Thomas et al (2017) menyatakan bahwa essensial oil daun EF yang diperoleh dengan cara hidrodestilasi dan dianalisis kromatografi gas-spektrometri massa (GC-MS) menunjukkan bahwa senyawa dominan adalah (E) -2-Dodecenal (28,43\%), 13tetradecenal $(27,45 \%)$, dodecanal $(14,59 \%)$ dan 2,4,5-trimethylbenzaldehyde (10,77\%). Lebih lanjut dinyatakannya bahwa senyawa dominan dari batang adalah dodecanal (20,21\%), 2,4,5-trimethylbenzaldehyde $(18,43 \%)$ dan (E) -2-dodecenal $(8,27 \%)$, sedangkan pada akar 2,4,5trimethylbenzaldehyde $\quad(56,08 \%), \quad 13-$ tetradecenal $(9,26 \%)$ dan (E) -2-dodecenal $(7,65 \%)$. Hasil hidrodestilasi yang dianalis dengan GC dan GC/MS menunjukkan bahwa EF memiliki komponen utama adalah 2,4,5 trimetil benzal aldehid (27,7\%), (E)-2 dodecanal $(27,5 \%)$, carotol $(8,8 \%), 3-$ dodecanal $(5,2 \%)$ dan $\gamma$-terpinene $(3,5 \%)$ (Cardozo et al 2004).

\section{Manfaat}

Beberapa spesies genus Eryngium digunakan sebagai rempah-rempah dan digunakan untuk pengobatan hipertensi, masalah pencernaan, asma, luka bakar, demam, diare, malaria (Erdem et a 2015).

\section{Anti Inflamasi Dan Antioksidan}

Inflamasi merupakan peradangan yang diakibatkan masuknya benda asing, patogen ke dalam tubuh. Eryngium foetidum (EF) digunakan dalam pengobatan tradisional untuk pengobatan beberapa gangguan anti inflamasi. Ekstrak ekstrak heksana EF dan stigmasterol mengakibatkan berkurang edema dalam proporsi yang sama dalam dua model tes (akut dan kronis). Aktivitas meloperoxidase sangat berkurang baik oleh ekstrak EF dan stigmasterol, dalam model akut tetapi tidak kronis. Ekstrak daun EF efektif melawan topikal proses peradangan. Stigmasterol juga memberikan aktivitas antiinflamasi topikal yang signifikan tidak dapat dianggap sebagai agen antiinflamasi utama, oleh karena itu komponen bioaktif lainnya mungkin terlibat dalam aktivitas ekstrak heksana (Garcia et al 1999). Aktivitas anti-inflamasi dapat dievaluasi dengan mengacu pada ekspresi gen iNOS, COX-2, TNF- $\alpha$ dan IL-6 (Mekhora et al 2012).

Metabolit sekunder yang terdapat di daun EF merupakan senyawa yang bertanggung jawab atas aktivitas anti-inflamasi dan antioksidan. Sekitar 24\% $\beta$-karoten dan 35\% lutein ditemukan dalam ekstrak air daun EF (Dawilai, et al 2013). Transfer caffeic dan asam klorogenik ke fraksi berair adalah $76 \%$ $81 \%$, sedangkan kaempferol sebesar $48 \%$ (Dawilai, et al 2013.) Ekstrak etanol EF terbukti mengandung lutein, $\beta$-karoten, asam klorogenat, kaempferol dan asam caffeic, senyawa yang dikenal memiliki sifat bioaktif anti inflamasi (Mekhora et al 2012).

Penelitian ini menilai aktivitas antiinflamasi dan antioksidan dari ekstrak daun E. foetidum pada makrofag murine yang diaktifkan LPS. Sel RAW yang diberi perlakuan awal dengan atau tanpa ekstrak EF selama 1 jam sebelum inkubasi dengan LPS selama 24 jam menunjukkan aktivitas anti inflamasi (Mekhora et al 2012). Aktivitas anti-inflamasi dapat dievaluasi dengan 
mengacu pada ekspresi gen iNOS, COX-2, TNF- $\alpha$ dan IL-6 (Mekhora et al 2012). Perlakuan dengan ekstrak EF menghambat peningkatan IL- 6 , TNF- $\alpha$, iNOS dan COX-2, bersama-sama dengan mRNA dengan cara yang tergantung pada dosis yang mengakibatkan kandungan NO dan ROS intraseluler berkurang (Mekhora et al 2012). Ekstrak daun EF memiliki efek supresif terhadap mediator proinflamasi sehingga memiliki potensi tinggi untuk digunakan sebagai suplemen makanan untuk mengurangi risiko kanker yang terkait dengan peradangan (Mekhora et al 2012).

Essensial oil yang diperoleh dengan cara hidrodestilasi dan dianalisis kromatografi gas-spektrometri massa (GC-MS). Kapasitas radikal bebas pembersihan minyak atsiri ditentukan dengan menggunakan 2, 2-difenil1-pikrillhidrazil (DPPH) dan pengujian daya antioksidan mengurangi (FRAP) besi. Hasil: Minyak atsiri daun EF mengandung terkandung proporsi tinggi (E) -2-Dodecenal (28,43\%), 13-tetradecenal $\quad(27,45 \%)$, dodecanal $\quad(14,59 \%)$ dan $2,4,5-$ trimethylbenzaldehyde $(10,77 \%)$; minyak batang terdiri dari dodecanal $(20,21 \%), 2,4,5-$ trimethylbenzaldehyde $(18,43 \%)$ dan (E) -2dodecenal $(8,27 \%)$, sedangkan 2,4,5trimethylbenzaldehyde $(56,08 \%)$, 13 tetradecenal $(9,26 \%)$ dan (E) -2-dodecenal $(7,65 \%)$ adalah yang paling dominan dalam minyak akar.Nilai IC50 untuk minyak daun, batang dan akar masing-masing adalah 56 $\mu \mathrm{g} / \mathrm{mL}, 46 \mu \mathrm{g} / \mathrm{mL}$ dan $54,5 \mu \mathrm{g} / \mathrm{mL}$ dalam uji DPPH sementara minyak daun menunjukkan potensi pengurangan tertinggi di antara minyak ujidalam uji FRAP. Kesimpulan: Minyak atsiri Nigeria $E$. foetidum mengandung jumlah tinggialdehida asiklik dan senyawa aromatik. Minyak adalah sumber potensial antioksidan alami ditunjukkan oleh aktivitas antioksidan yang kuat (Thomas et al 2017).

\section{Anti Mikoba}

Pemanfaatan tumbuhan sebagai anti mikroba telah lama dilakukan baik secara langsung maupun tidak langsung. Penambahan berbagai jenis rempah pada berbagai jenis makanan secara langsung maupun tidak langsung dapat meningkatkan keawetan makanan. Silalahi (2017) menyatakan bahwa penambahan Etlingera elatior pada arsik (sejenis gulai ikan mas) mengakibatkan makanan menjadi lebih tahan lama. Hal tersebut mengekibatkan berbagai jenis tumbuhan sangat potensial digunakan sebagai pengawet alami.

Tumbuhan yang digunakan sebagai anti mikroba merupakan tumbuhan yang menghasilkan senyawa yang mampu menghambat pertumbuhan atau mengakibatkan kerusakan mikroba. Berbagai peneliti telah melaporkan aktivitas EF sebagai anti mikroba terhadap Listeria monocytogenes (Ngang et al 2014) dan Helicobacter pylori (Mabeku et al 2013), Escherichia coli, Pseudomonas aeruginosa, Staphylococcus aureus susp. Aureus dan Strptococcus pneumoniae (Begum et al 2018). Kandungan essensial oil merupakan senyawa yang yang menghamabat pertumbuhan mikroba (Ngang et al 2014). Ekstrak daun EF yang digunakan untuk biosintesis nanopartikel $\mathrm{ZnO}$ menunjukkan yang sangat baik agen antibakteri terhadap bakteri patogen seperti Escherichia coli, Pseudomonas aeruginosa, Staphylococcus aureus susp. Aureus dan Strptococcus pneumoniae. Zona penghambatan maksimum di $\mathrm{ZnO}$ yang mengandung ekstrak EF sebesar $32,23 \pm 0,62$ dan $28,77 \pm 1,30 \mathrm{~mm}$ untuk P. aeruginosa dan E. coli secara berurutan (Begum et al 2018)

Kemampuan EF sebagai anti mikroba dipengaruhi oleh berbagai faktor seperti konsentrasi (Ngang et al 2014). Penggunaan ekstrak etanol EF dengan konsentrasi 15 ppm selama pasteurisasi jus nanas pada suhu 600C berimplikasi terhadap waktu yang dibutuhkan untuk pengurangan 4-log dalam L. monocytogenes $\mathrm{CFU} / \mathrm{ml}$ sebesar $74,9 \%$ (dari 8,5 menjadi 2,1 menit) dibandingkan dengan pengobatan tanpa ekstrak EF (Ngang et al 2014). Pasteurisasi yang dibantu EF merupakan strategi yang menjanjikan untuk pengurangan dampak termal selama produksi jus sehingga dapat aplikasikan dalam industri makanan (Ngang et al 2014).

Mabeku et al (2013) melaporkan bahwa ekstrak EF memiliki aktivitas anti bakteri terhadap 6 strain klinis Helicobacter pylori secara in vitro dan in vivo. Ekstrak metanol EF dengan konsentrasi 125, 250, dan 500 
$\mathrm{mg} / \mathrm{kg}$ dan ciprofloxacin $(500 \mathrm{mg} / \mathrm{kg}$ sebagai kontrol) yang diberikan selama 7 hari pada tikus Swiss yang diinokulasi dengan $\mathrm{H}$. pylori mampu menekan infeksi $\mathrm{H}$. pylori. Mabeku et al (2013) menyatakan bahwa jumlah hewan yang terinfeksi $H$. pylori hanya $17 \%$ ketika diberi ekstrak EF sedangkan yang tidak diberikan terinfeksi $100 \%$. Jumlah ini memang masih lebih tinggi dibandingkan dengan kontrol yaitu $0 \%$ dengan pemeberian ciprofloxacin. Ekstrak tumbuhan (381.9 \pm 239.5 CFU) dan ciprofloxacin (248 $\pm 153.2 \mathrm{CFU})$ secara signifikan mengurangi massa bakteri dalam mukosa lambung dibandingkan dengan tikus yang tidak diinokulasi dan diinokulasi (14350 \pm 690 CFU) (Mabeku et al 2013).

\section{SimPUlan DAN SARAN}

Secara etnobotani Eryngium foetida digunakan untuk mengatasi demam, hipertensi, sakit kepala, sakit perut, asma, radang sendi, diare, dan malaria. Essential oil yang terdapat pad EF didominasi oleh (E) -2dodecenal, asam dodecanoic, asam trans-2dodecanoic $(9,7 \%)$, (E) -2-tridecenal, duraldehyde, dan tetradecanal. Bioaktivitas EF telah terbukti sebagai anti mikroba, antioksidan dan anti infalamasi..

\section{DAFTAR PUSTAKA}

[1] Begum S, M. Ahmaruzzaman, PP Adhikari. 2018. Ecofriendly biosynthetic route to synthesize $\mathrm{ZnO}$ nanoparticles using Eryngium foetidum L. and their activity against pathogenic bacteria. Materials Letters 228 (2018) $37-41$.

[2] Bhavana GP, Chandrika R and KJT Saraswathi. 2013. Quantitative determination of secondary compounds in populations of Eryngium foetidum L. from India. Int J Curr Sci 2013, 9: E 2428

[3] Cardozo E, M Rubio, LB Rojas and A Usubillaga. 2004. Composition of the Essential oil from the leaves of Eryngium foetidium L. from the Venezuelan Andes. J. Essent. Oil Res. 16: 33-34.
[4] Chowdhury JU, NC Nandi and M Yusuf. 2007. Chemical Constituents of Essential Oil of the Leaves of Eryngium foetidum from Bangladesh. Bangladesh J. Sci. Ind. Res. 42(3), 347-352, 2007.

[5] Dawilai S, C Muangnoi, P. Praengamthanachoti, and S Tuntipopipat. Anti-Inflammatory Activity of Bioaccessible Fraction from Eryngium foetidum Leaves Hindawi Publishing Corporation. BioMed Research International Volume 2013, Article ID 958567, 8 pages http://dx.doi.org/10.1155/2013/958567: page 1-11

[6] De Guzman CC and JS Siemonsma. 1999. Plant Resources of South East Asia No 13 Spices, Bachyus Publisher, Leiden, The Netherlands 440 pp

[7] Erdem SA, SF Nabavi, IE Orhan, M Daglia, M Izadi and SM Nabavi. 2015. Blessings in disguise: a review of phytochemical composition and antimicrobial activity of plants belonging to the genus Eryngium. Journal of Pharmaceutical Sciences (2015) 23:53

[8] Garcia, M.D., M. T. Saenz, M. A. Go'mez and M. A. Fernandez. 1999. Topical Antiinflammatory Activity of Phytosterols Isolated from Eryngium foetidum on Chronic and Acute Inflammation Models. Phytotherapy Research 13, 78-80 (1999)

[9] Martin AP, LR Salgueiro and AP da Cunha. 2003. Essential oil compositition of Eryngium foetidum from S.Tomee Principe. J. Essent.Oil Res. 15: 93-95

[10] Mabeku LBK, BE Bille, and E Nguepi. 2016. In Vitro and In Vivo AntiHelicobacter Activities of Eryngium foetidum (Apiaceae), Bidens pilosa (Asteraceae), and Galinsoga ciliata (Asteraceae) against Helicobacter pylori Hindawi Publishing Corporation BioMed Research International. Volume 2016, Article ID 2171032, 7 pages http://dx.doi.org/10.1155/2016/2171032

[11] Ngang, JJE., MA. Nyegue, FC. Ndoye, ADT Kamgain, SLS Kamdem, R Lanciotti, F Gardini, \& FX Etoa. 2014. 
Characterization of Mexican Coriander (Eryngium foetidum) Essential Oil and Its Inactivation of Listeria monocytogenes In Vitro and during Mild Thermal Pasteurization of Pineapple Juice. Journal of Food Protection, Vol. 77, No. 3, 2014, Pages 435-443.

[12] Mekhora C, C Muangnoi, $P$ Chingsuwanrote, S Dawilai, S Svasti, K Chasri, \& S Tuntipopipat. 2012. Eryngium foetidum Suppresses Inflammatory Mediators Produced by Macrophages. Asian Pacific Journal of Cancer Prevention, Vol 13:653 -664

[13] Ngang JJE, MA Nyegue, FC Ndoye, ADT Kamgain, SLS Kamdem, R Lanciotti, F Gardini,3 FX ETOA. 2014.Characterization of Mexican Coriander (Eryngium foetidum) Essential Oil and Its Inactivation of Listeria monocytogenes In Vitro and during Mild Thermal Pasteurization of Pineapple Juice. Journal of Food Protection 77(3) : 435-443

[14] Oyen LPA and NX Dung. (1999). Plant Resources of South East Asia No 19. Essential Oil Plants, Bachyus Publishers, Leiden, The Netherlands, 277pp.

[15] Singh BK, Y. Ramakrishna, SV Ngachan. 2014. Spiny coriander (Eryngium foetidum L.): a commonly used, neglected spicing-culinary herb of
Mizoram, India. Genet Resour Crop Evol. DOI 10.1007/s10722-014-0130-5 Page 1-6

[16] Silalahi, M. 2017. Senyawa Metabotit Sekunder Pada Etlingera elatior (Jack) R. M. Smith. Prosiding Seminar Nasional Pendidikan Biologi dan Sainteks. Universitas Muhammadiyah, Surakarta, 2017.

[17] Taiz, L. \& E. Zeiger. Plant Physiology. Sinauer Associates, Inc, Sunderland: xxvi +764 hlm .

[18] Thomas PS, EE. Essien, SJ. Ntuk and MI. Choudhary. 2017. Eryngium foetidum L. Essential Oils: Chemical Composition and Antioxidant Capacity. Thomas PS, EE. Essien, SJ. Ntuk and MI. Choudhary. 2017. Medicines 2017, 4, 24; doi:10.3390/medicines4020024: 17

[19] Wang P, Z Su, W Yuan, G Deng and S Li. 2012. Phytochemical Constituents and Pharmacological Activities of Eryngium L. (Apiaceae). Pharmaceutical Crops, 2012, 3, 99-120.

[20] Van den Bergh 1999. Eryngium foetidum L. Dalam de Guzman CC and JS Siemonsma 1999. Plant Reseources of South East Asia No 13. Spices. Bachyus Publisher, Leiden, The Netherlands P. 121-12 